\title{
ANALYSIS OF COST AND RETURNS IN RICE PRODUCTION BY USAID-MARKETS II PROJECT PARTICIPANTS AND NON-PARTICIPANTS IN EBONYI STATE, NIGERIA
}

\author{
Ogechi Cordelia Nwahia \\ Department of Agricultural Economics, Ahmadu Bello University, Zaria \\ corresponding author: godstime_ogefine@yahoo.com.+2348065151206
}

\begin{abstract}
This research work focused on analysis of cost and returns in rice production by USAID-MARKETS II project participants and non-participants in Ebonyi state, Nigeria. Multi-stage sampling procedure was employed to select 239 participants, and 252 non- participants for the study. Data were collected from primary source, and analyzed using Z statistic, Net Farm Income (NFI) and Returns Per Naira Invested (RNI). The result reveals that the Net Farm Income (NFI) obtained by USAID-MARKETS II project participants, and nonparticipants were $\mathrm{N} 493,067.55 /$ ha, and $\$ 353,408$. 12/ha respectively while the return on investment obtained by them were $\mathrm{N} 3.28 \mathrm{k}$, and $\mathrm{N} 3.05 \mathrm{k}$ respectively. There was a significant difference between the profits obtained by them. Therefore, this study recommended that the teaming unemployed Nigerian youth should be encourage by the government, and international agencies through provision of grant/loan to take up rice farming as a business.
\end{abstract}

Keywords: Comparative Analysis, Profitability, Rice Production, Rice farming households, USAID-MARKETS II project

\section{INTRODUCTION}

Rice is a very important stable food in Nigeria, and it is cultivated in all the agro-ecological zones in Nigeria. Nigeria is blessed with good climatic, vegetation, and soil conditions suitable for rice production. The demand for rice will continue to grow in Nigeria, due to rapid growth in population (IFPRI, 2016). Nigeria ranked as the highest importer of rice in West Africa, and the second largest rice importer in the world, after Indonesia (Cadoni, and Angelucci, 2013) as cited in (Onyekwena, 2016). Despite many policies made by Nigerian government in the rice sector, rice production has failed to keep pace with the growing domestic demand. In 2014, rice demand was estimated at 5.9 million metric tonnes (MT) while only 2.7 million MT was produced locally, leaving a supply gap of 3.2 Million MT (Sahel Capital Partners \& Advisory Limited, 2015). The need to bridge the gap between rice demand, and supply has led to increases in rice imports. It was reported that Nigeria spent N1billion per day on rice imports in 2013 (Onyekwena, 2016). These necessitated Nigerian government intervention in the rice sector. USAID-MARKETS II is one of such intervention in Nigerian rice sector. USAID is an international agency that provides foreign aids to needy countries. The agency's intervention in agricultural production is known as Maximizing Agricultural Revenue, and Key Enterprises in Targeted Sites (MARKETS). MARKETS worked along the rice value chain in order to improve productivity, income, sales, and jobs at firm, and farm levels (USAID, 2013). USAID MARKETS was initiated in 2005 and designed to expand economic opportunities in Nigeria's agricultural sector. Over time, USAIDMARKETS have grown to provide farmers with assistance such as fertilizer supply, and technology development; seed development, and farmers training (USAID-MARKETS, 2010). USAID

CITATION: Nwahia, O., C., (2021). Analysis of Cost and Returns in Rice Production by USAID-MARKETS II Project Participants and non-Participants in Ebonyi State, Nigeria, Agricultural Socio-Economics Journal, 21(1), 1-6 DOI: http://dx.doi.org/10.21776/ub.agrise.2021.021.1.1 
MARKETS II project was initiated to assist rice producers with adequate knowledge, and skills to enhance rice productivity, income, and their wellbeing (USAID-MARKETS, 2010; USAIDMARKETS, 2014).

Despite the interventions of the Nigerian government in the rice sector, low rice profitability have continued to be a major problem that discouraged the Nigerian farmer from venturing into rice farming. Therefore, this research work aims to analyze the cost, and returns in rice production by USAID-MARKETS II project participants, and nonparticipants in Ebonyi state, Nigeria, with the intention of discovering better techniques in rice production that could generate more profits for the rice farmers. A null hypothesis which stated that there is no significant difference between the profit obtained in rice production by participants, and nonparticipants of USAID-MARKETS II was tested.

\section{METHODOLOGY}

The study was conducted in Ebonyi State. Ebonyi state was created in 1996, making it one of the youngest states in Nigeria. Agriculture is a major occupation in Ebonyi State, with an estimated 85\% of the population earning their living from one form of agriculture or another. Ebonyi State has a total land area of about $5,935 \mathrm{~km}^{2}$ (Obasi, Agbo, and Onyenekwe, 2015). Ebonyi State is located within latitude $7^{0} 30 \mathrm{E}$, and $8^{0} 30 \mathrm{E}$, and longitude $6^{0} 40 \mathrm{~N}$, and $6^{0} 45 \mathrm{~N}$ of South East zone of Nigeria. Ebonyi is made up of thirteen local government areas (LGAs) with a total population projected with an estimated growth rate of $3 \%$ to be 3.1 million people in 2020 .

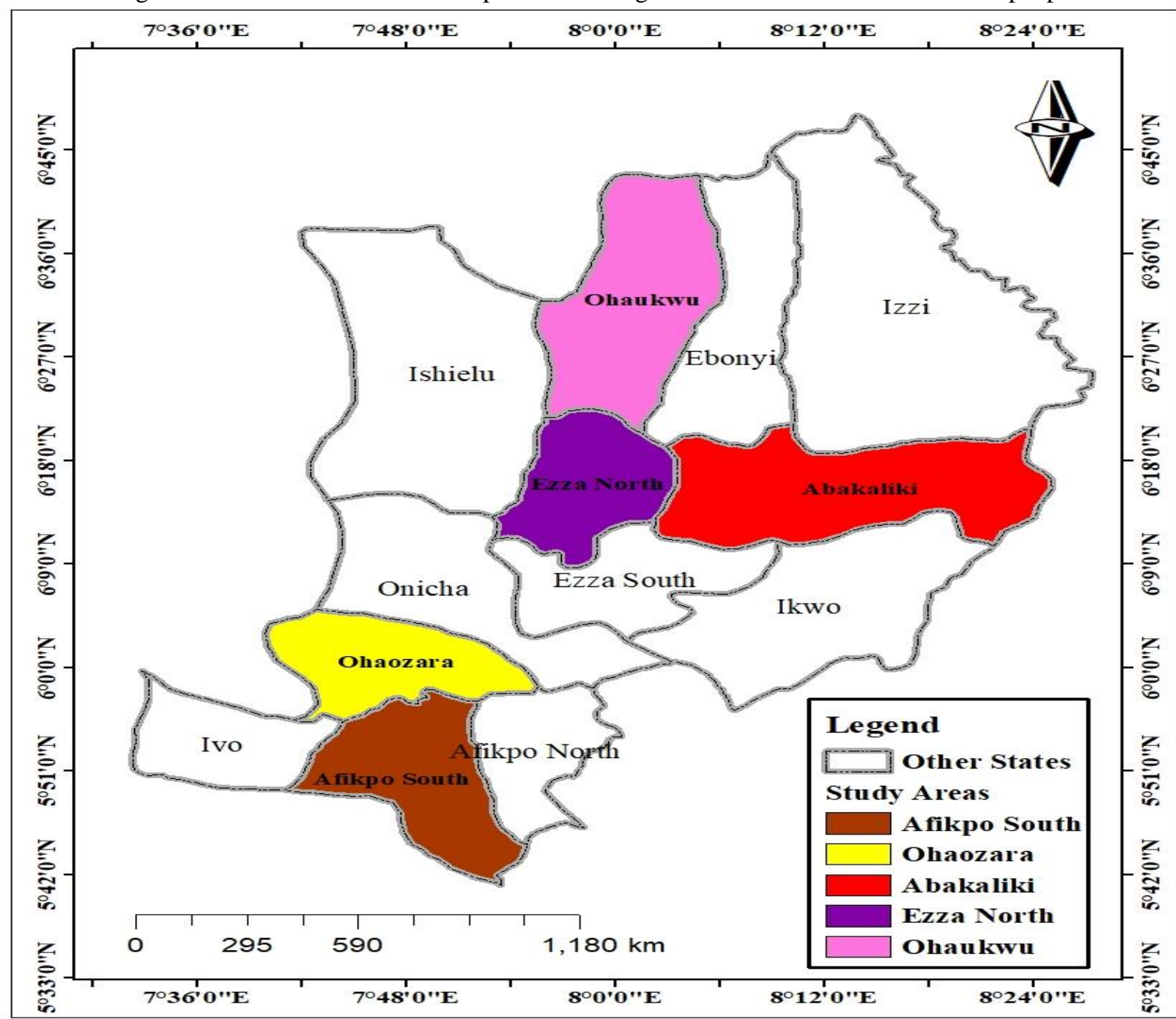

Source: Administrative map of Nigeria

MAP OF EBONYI STATE SHOW ING STUDY AREAS

Fig 1: Map of Ebonyi State showing the study areas. 


\section{DATA COLLECTION AND SAMPLING TECHNIQUE}

Multi-stage sampling procedures were used for this study. In the first stage, 4 Local Government Areas (LGA) out of 12 that participated in the USAID-MARKETS II project in Ebonyi State were randomly selected. In the second stage, 3 villages each were randomly selected from the 4 LGAs making a total of 12 villages. In the third stage, 239 participating rice farming households were selected from the list of USAID-MARKETS II Participants (UMP) in 12 sampled villages, using the Yemen (1967) scientific formula for calculating sample size.

Yemen (1967) scientific formula that was adopted in this study is given as $\mathrm{n}=\frac{N}{1+N\left(\propto^{2}\right)}, 5 \%$ room for error was given and 95 percent confidence level in selecting the sample size. Where $\mathrm{n}$ is the sample size, $\mathrm{N}$ is the sample frame and $\propto^{2}$ is the precision level (0.05). In order to control for spillover effect, 6 villages were randomly selected from one LGA that did not participate in USAIDMARKETS II project in Ebonyi state to serve as the control group. Also, from the list of NonpParticipants of USAID-MARKETS II (NPUM), using the Yemen scientific formula for calculating sample size, 252 non- participating rice farming households were selected from the 6 sampled villages. In all, a total sample size of 491 rice farming households were selected for the study. Data used in the study were collected from primary source with the aid of structured questionnaire, and field observations. Data collected were analyzed using descriptive statistics, Z statistic, Net Farm Income (NFI), and Returns Per Naira Invested (RNI) model.

\section{Net Farm Income Model}

Net Farm Income statement is a summary of revenue, and expenses for a given accounting period (usually one year). The Net Farm Income (NFI) was used in this study to measure the difference between revenue, and expenses of UMP, and NUMP in rice farming. A Positive difference indicates a profit while a negative difference indicates a loss for the farming period. The approach suggested by the Cost of Cultivation for Principal Crops as adopted by Durga, and Suresh, (2013) was used to calculate the returns on rice farming. The total cost of farming comprises of fixed, and variable costs. Fixed cost includes land payment, depreciation on farm tools, and Implements, for owned land, rental value of the land was used. The variable cost includes cost of seeds, fertilizers, agrochemicals, labour, and interest on working capital. Interest on working capital was calculated at the rate of banks short-term loans. It was calculated for the duration of the rice crop. Net income is the difference between the gross return, and total cost of farming as stated below

Net income $=\mathrm{GR}-\mathrm{TC}$.

Where GR = gross return (value of the paddy in naira)

$\mathrm{TC}=$ total cost of farming

While $\mathrm{TC}=\mathrm{FC}+\mathrm{VC}$

Where: $\quad \mathrm{FC}=$ fixed cost and $\mathrm{VC}=$ variable cost .

\section{Returns Per Naira Invested (RNI) Model}

Returns Per Naira invested $(\mathrm{RNI})=\frac{T R}{T C}$.

Where RNI $=$ Returns Per Naira invested

$\mathrm{TR}=$ Total revenue in naira

$\mathrm{TC}=$ Total cost of rice production in naira

If RNI is less than unity, it means it is unprofitable to embark on the investment at the present production level, and/or the present production price level. If RNI is more than unity, it means it is profitable to engage in producing the product at the present production level, and/or the present production price level. If RNI is equal to unity, it means it is neither unprofitable nor profitable to engage in producing the product at the present production level, and/or the present production price level that is it is breakeven point.

\section{RESULTS AND DISCUSSION}

Profitability of Rice Production among Participants, and Non-Participants of USAIDMARKETS II.

The result of the Net Farm Income (NFI), and Return on Naira Invested used to determine the profitability of rice production among USAIDMARKETS II participants, and non-participants in Ebonyi state are presented in Table 1. The result in Table 1 reveals that the participants of USAIDMARKETS II used an average of $92 \mathrm{~kg}$ of rice seed per hectare, which is within the recommended rate of $50-100 \mathrm{~kg}$ rice seed per hectare while the nonparticipants of USAID-MARKETS II used $117.11 \mathrm{~kg}$ of rice seed per hectare. The reason for these difference in rice seed usage may be as a result of the training carried out by the officials of USAIDMARKETS II on the participants. For the fertilizer 
usage, the recommended rate is between $200-$ $250 \mathrm{~kg} / \mathrm{ha}$ of NPK in the ratio of $80-100 \mathrm{~N}, 30-50 \mathrm{P}$ and $30-50 \mathrm{~K}$ because of more nitrogen need of rice plant. The participants of USAID-MARKETS II project used an average of $232.41 \mathrm{~kg} / \mathrm{ha}$ of fertilizer, which is within the recommended rate while the non-participants used $145.32 \mathrm{~kg} /$ ha of fertilizer. For the herbicide, the recommended rate in Nigeria is between 12 - 13litres/hectare. The sampled participants used an average of 10.3litre/ha of herbicide while the non-participants used 2.5 litre/ha of herbicide. The yields obtained from rice farm by participants, and non-participants was 5.273tonnes/ha, and 3.496 tonnes/ha of paddy rice respectively; the participants are within the expected/potential yield of between 5 - 6tons/ha using improved practice while the non-participants rice yield was less than the expected/potential yield per hectare. From the result in Table 1, participants obtained higher yield from rice farm than the nonparticipants. The reason for this difference may be due to the adherent to the best practices by participants as was taught by the USAIDMARKETS officials/extension agents.

Also, the result presented in Table 1 shows that the total cost incurred in rice production by participants, and non-participants of USAID-MARKETS II was N223, 841.37, and $\mathrm{N} 116,114.22$ per hectare respectively. The total cost of rice production incurred by the participants was higher than that of the non-participants. This could be attributed to the fact that most of the System of Rice Intensification (SRI), and agronomy practices adopted by the participants (line planting, nursery making, transplanting among others) are cost effective. The total revenue/ha realize by the participants, and nonparticipants of USAID-MARKETS II in rice production was N716, 908.92, and N529, 522.34 respectively. Also, the total revenue obtain by the participants was higher than that of non-participants. The Net Farm Income (NFI) obtain by UMP, and NPUM was N493, 067.55/ha, and N353, 408. 12/ha respectively, which indicates that rice production is profitable in the study area. This findings is in agreement with the works of Ben-Chendo et al., (2017) who revealed a net farm income of $\$ 152,600 /$ ha in paddy rice production in Kaduna state, Girei et al., (2016) who found a net farm income of $\mathrm{N} 469,136.00$ per hectare in rice production in Fufore Local Government Area of Adamawa state, and Kadiri et al., (2014) who found a net farm income of $\mathrm{N} 300,071.84$ per hectare in paddy rice production in Niger Delta region of Nigeria. The higher difference in NFI of participants over that of non-participants may be attributed to increase in yield realized by the participants of USAID-MARKETS II because they were taught better rice farming techniques which had impacted on their output, and revenue.

The return on investment for UMP, and NPUUM was $\mathrm{N} 3.28 \mathrm{k}$, and $\mathrm{N} 3.05 \mathrm{k}$ respectively. This implies that for every one naira (N1.00) invested by the participants, and non-participants of USAID-MARKETS II in rice production, a profit of $\mathrm{N} 2.28 \mathrm{k}$, and $\mathrm{N} 2.05 \mathrm{k}$ were realized respectively, implying that rice production is profitable in the study area. It is therefore more profitable for the participants, and non-participants to invest in rice production than to invest in Nigerian banking sector through savings. This is because using the $12 \%$ annual interest rate on savings in Nigerian banks, every $\mathrm{N} 1$ invested in the bank will generate $\mathrm{N} 1.12$ at the end of the year with a profit of $\mathrm{N} 0.12$ which is far below $\mathrm{N} 2.28$, and $\mathrm{N} 2.05 \mathrm{k}$ profit realized from rice production by UMP, and NPUM in Ebonyi state. This findings agrees with Girei et al., (2016) who reveals return on investment of $\mathrm{N} 1.37$ in rice production in Fufore Local Government Area of Adamawa state, Nigeria.

\section{Difference in Net Farm Income (NFI) of Rice Production among UMP, and NPUM.}

The result of Z-test on the significance difference in NFI among UMP, and NPUM farming households are presented in Table 2 . The result shows that the value of $\mathrm{Z}$ - calculated is greater than that of $\mathrm{Z}$ critical. This implies that there is a significant difference between the profit obtained in rice production by the participants, and non-participants of USAID-MARKETS II at $1 \%$ level. Therefore, the null hypothesis which stated that there is no significant difference between the profit of participants, and non-participants of USAIDMARKETS II was rejected.

\section{CONCLUSION/RECOMMENDATION}

This research work which centered on analysis of cost, and returns in rice production by USAID-MARKETS II project participants, and nonparticipants in Ebonyi state, Nigeria establishes that rice farming is very profitable in Ebonyi state. There was a significant difference between the profit 
obtained from rice farming by participants, and nonparticipants of USAID-MARKETS II at $1 \%$ level. The System of Rice Intensification (SRI) practices adopted by USAID-MARKETS II project participants is very beneficial in rice production. Therefore, Nigerian government, and individuals should invest more in Ebonyi rice production through inputs supply, and adequate training of the rice farmers on improved rice production techniques. Also, the teaming unemployed Nigerian youth should be encourage by the government, and international agencies through provision of grant/loan to take up rice farming as a business for tremendous profit.

Table 1: Profitability of Rice Production among USAID-MARKETS II Participants, and Non-participants

\begin{tabular}{|c|c|c|c|c|c|c|}
\hline Var/ha & Ave qty & $\begin{array}{l}\text { UMP } \\
\text { Unit price } \\
\mathrm{N} / \mathrm{Ha}\end{array}$ & $\begin{array}{l}\text { Ave. cost } \\
\mathrm{N} / \mathrm{Ha}\end{array}$ & $\begin{array}{l}\text { Ave qty } \\
\mathrm{N} / \mathrm{Ha}\end{array}$ & $\begin{array}{l}\text { NPUM } \\
\text { Unit price } \\
\mathrm{N} / \mathrm{Ha}\end{array}$ & $\begin{array}{l}\text { Ave. cost } \\
\mathrm{N} / \mathrm{Ha}\end{array}$ \\
\hline \multicolumn{7}{|l|}{ Fixed inputs } \\
\hline Depreciation & & & $3,819.59$ & & & $2,222.24$ \\
\hline Land rent & & & $23,991.12$ & & & $25,049.80$ \\
\hline Total Fixed cost & & & $27,810.71$ & & & $27,272.04$ \\
\hline \multicolumn{7}{|l|}{ Var inputs } \\
\hline Fert(Kg) & 141.66 & 856.39 & $121,316.21$ & 140.19 & 724.15 & $101,518.58$ \\
\hline Seed(Kg) & 232.41 & 145.78 & $33,880.73$ & 145.32 & 130.85 & $19,015.12$ \\
\hline Herb(li) & 92 & 192.03 & $17,666.76$ & 117.11 & 162.55 & $19,036.23$ \\
\hline Interest(N) & 10.3 & $1,732.09$ & $17,840.53$ & 2.5 & $2,775.75$ & $6,939.38$ \\
\hline $\begin{array}{l}\text { Total Variable } \\
\text { cost }\end{array}$ & $\begin{array}{l}106,528.6 \\
196,030.66\end{array}$ & $5 \%$ & $5,326.43$ & $46,657.4$ & $5 \%$ & $\begin{array}{l}2,332.87 \\
148.842 .18\end{array}$ \\
\hline Total farming & $190,050.00$ & & & & & $148,842.18$ \\
\hline $\begin{array}{l}\text { cost } \\
\text { Farming cost - }\end{array}$ & & & $223,841.37$ & & & $176,114.22$ \\
\hline $\begin{array}{l}\text { interest } \\
\text { Output }(\mathrm{Kg})\end{array}$ & & & $218,514.94$ & & & $173,781.35$ \\
\hline Total Rev(TR) & $5,272.94$ & 135.96 & $716,908.92$ & $3,296.12$ & 151.46 & $529,522.34$ \\
\hline NFI & & & $716,908.92$ & & & $529,522.34$ \\
\hline TR/TC & & & $493,067.55$ & & & $353,408.12$ \\
\hline RNI & 3.28 & & & 3.05 & & \\
\hline & 3.28 & & & 3.05 & & \\
\hline
\end{tabular}

Source: Field Survey, 2018.

Table 2: Z-test on Difference in profitability of UMP, and NPUM in rice production.

\begin{tabular}{|c|c|c|c|c|}
\hline variables & & Participants Net-farm Income(N) & $\begin{array}{l}\text { Non-Participants } \\
\text { Income }(\mathrm{N})\end{array}$ & Net-farm \\
\hline Mean & & 493067.9 & 353408.9 & \\
\hline Known variance & & $6.73 E+11$ & $6.12 \mathrm{E}+9$ & \\
\hline Observation & & 234 & 242 & \\
\hline $\begin{array}{l}\text { Hypothesized } \\
\text { Difference }\end{array}$ & Mean & 0 & & \\
\hline z-stat & & $4.70045^{* * *}$ & & \\
\hline $\mathrm{P}(\mathrm{Z}<=\mathrm{z})$ one tail & & 0.00001 & & \\
\hline $\mathrm{z}$-critical one tail & & 1.644854 & & \\
\hline $\mathrm{P}(\mathrm{Z}<=\mathrm{z})$ two tail & & 0.00003 & & \\
\hline z-critical two tail & & 1.959964 & & \\
\hline
\end{tabular}

Source: Field Survey, 2018. 


\section{REFERENCES}

Ben-Chendo, G. N., Lawal, N., and Osuji, M. N. (2017) 'Cost and Returns of Paddy Rice Production in Kaduna State', European Journal of Agriculture and forestry Research, 5(3) pp. 41-48.

Durga, A. R., and Suresh D. K. (2013) 'Economic Analysis of the System of Rice Intensification: Evidence from Southern India', Bangladesh Development Studies 36 (1)

Girei, A., Usman, I. S., and Onuk, E. G. (2016) 'Profitability Investigation of Rice Production in Fufore Local Government Area of Adamawa State, Nigeria', European Journal of Academic Essays, 3(3) pp. 137-140.

International Food Policy Research Institute (IFRRI). (2016) 'The Nigerian Rice Economy: Policy Options for Transforming Production, Marketing, and Trade', edited by Kwabena, G., Michael, J., and Hiroyuki T. University of Pennsylvania Press Philadelphia

Kadiri, F. A., Eze, C. C., Orebiyi, J. S., and Onyeagocha S. U. O. (2014) 'Resource-Use and Allocative Efficiency of Paddy Rice Production in Niger Delta Region of Nigeria', Global Journal of Agricultural Research, 2(4) pp. 11-18.

Obasi, F. A., Agbo, F. U., and Onyenekwe, S. C. (2015) 'Environmental and socio-economic effects of timber harvesting in Ebonyi State, Nigeria', African Journal of Agricultural Research,10(11) pp. 1233-1238.

Onyekwena, .C. (2016) 'Towards Rice SelfSufficiency in Nigeria: Comtemporary Issues and Challenges', A Power Point Presentation to Centre for the Study of the Economies of Africa (CSEA).

Sahel Capital Partners and Advisory Limited. (2015) 'Rice in Nigeria: Industry Dynamics', Sahel Capital Limited Vol 12.

USAID. (2013) 'MARKETS II Annual Work Plan 2013'.

USAID-MARKETS. (2014) 'Rice Value Chain out Growers Scheme in Ebonyi State, Nigeria', 2013 Project Completion Report.

USAID-MARKETS. (2010) 'Improved package of practices for rice production. Nigeria', Abuja.pg 1- 3.

Yemen Taro. (1967) 'Statistics: An Introductory Analysis', 2nd Edition, New York: Harper, and Row Zeigler, R.S (2006) Rice Research for Poverty Alleviation, and Environmental Sustainability in Asia. www.niaes.affre.go.jp/sinfo/sympo/hi8/20061 212pdf/s3_zeigler.pdf accessed on $27^{\text {th }}$ March, 2018. 